\title{
How to increase supplier flexibility through social mechanisms and influence strategies?
}

\author{
Po-Young Chu \\ Department of Management Science, National Chiao Tung University, Hsinchu, Taiwan \\ Kuo-Hsiung Chang \\ Department of International Business, Tunghai University, Taichung, Taiwan, and \\ Hsu-Feng Huang \\ Department of Management Science, National Chiao Tung University, Hsinchu, Taiwan
}

\begin{abstract}
Purpose - This study aims to examine the means by which influence strategies and social mechanisms (trust and shared vision) influence the flexibility of suppliers, and its ultimate effect on the performance of manufacturers.

Design/methodology/approach - This study bases the major components of marketing research on previous studies related to influence strategies and flexibility in the supply-chain. This empirical study utilized 162 SMIT survey samples.

Findings - Results show that using coercive influence strategies and developing a shared vision promote supplier flexibility and fully mediate the effects of trust on supplier flexibility. In addition, supplier flexibility has a significant positive impact on the performance of manufacturers.

Research limitations/implications - The perceptions of manufacturers regarding influence strategies and social mechanisms formed the basis of this study. Future studies could focus on the reciprocal strategies of suppliers, and the influence of these actions on the effectiveness of the influence strategies employed by manufacturers.

Practical implications - This paper adds to the existing management guidelines addressing the problem of ensuring increased flexibility from suppliers to enable a more rapid response to the demands of customers to enhance performance.

Originality/value - The paper provides novel insights into the impact of influence strategies and social mechanisms on the flexibility of suppliers.
\end{abstract}

Keywords Flexibility, Coercive influence strategies, Noncoercive influence strategies, Trust, Shared vision

Paper type Research paper

An executive summary for managers and executive readers can be found at the end of this article.

\section{Introduction}

Supplier flexibility refers to the ability of suppliers to manage production resources and uncertainty to enhance flexibility in meeting the variable demands of buyers. Because the processes involved in supply chain management extend beyond the boundaries of individual firms, supplier flexibility enhances the capabilities of manufacturers to improve performance. Supplier flexibility has become a criterion for winning orders. Flexibility is a reaction to dynamic environments (Giunipero et al., 2005; Upton, 1995; Vickery et al., 1999), and as such, is an important relational norm in inter-organizational relationships (Ivens, 2005). Supplier flexibility has become an extremely important issue in today's rapidly changing markets, and due to the growing importance of purchasing as a means to improve the supply

The current issue and full text archive of this journal is available at www.emeraldinsight.com/0885-8624.htm

Journal of Business \& Industrial Marketing 27/2 (2012) 115-131

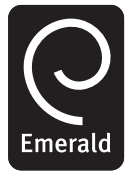

(C) Emerald Group Publishing Limited [ISSN 0885-8624] [DOI 10.1108/08858621211196985] chain. A flexible supplier can increase a manufacturer's competitive advantage by improving response time to the ever-changing demands of customers. Unfortunately, although responding to the requirements of manufacturers creates values for the manufacturer, it may also lead to a decrease in value for the supplier. Such flexibility implies that suppliers are able to provide additional service in response to changes in market demand, and although this flexibility benefits the manufacturer, it may come at a cost to the supplier. Suppliers generally provide either limited flexibility, or offer prices based on the level of flexibility desired by the manufacturer. Understanding the means by which manufacturers manage supply flexibility is a crucial issue for management and practice.

Alternative means of communication often utilize influence strategies in an attempt to motivate the compliance of a target. Previous studies have focused on the role of influence strategies in marketing channel relationships, such as reduced channel conflict (Frazier and Rody, 1991), satisfaction (Lai, 2007; Sanzo et al., 2003), relationalism (Boyle et al., 1992),

Received 10 September 2009

Revised 12 April 2010

1 February 2011

Accepted 3 March 2011

The authors thank Professor Wesley Johnston and the anonymous $\mathscr{F B I M}$ reviewers for comments on earlier versions of this research. 
and solidarity (Kim, 2000). In addition, many researchers view social capital as a set of relational resources embedded in relationships (Gulati et al., 2000; Nahapiet and Ghoshal, 1998). According to Nahapiet and Ghoshal (1998), social capital includes structural (represented by network position), relational (represented by trust), and cognitive dimensions (represented by shared vision among units of a group). Literature on inter-organizational trust in exchange relationships argues that trust exists when a party has confidence in the exchange partners' reliability and integrity (Gulati et al., 2000; Morgan and Hunt, 1994; Ring and Van de Ven, 1992). Trust can also facilitate inter-organizational communication and information sharing, which enhances responsiveness (Handfield and Bechtel, 2002) and performance (Dirks and Ferrin, 2001; Zaheer et al., 1998). Furthermore, Tsai and Ghoshal (1998) declared that a shared vision embodies the collective goals and aspirations of the members of the organization. Empirical studies have shown that parties in supply chains with a shared vision perform at a higher level (e.g. Spekman et al., 1999).

Researchers have found that influence strategies potentially change the attitudes and behavior of other actors (Mohr and Nevin, 1990), and that social capital facilitates interorganizational communication and the sharing of information as a means to improve responsiveness (Handfield and Bechtel, 2002). However, little is known about the effectiveness of influence strategies and social capital with regard to the motivation of suppliers to enhance flexibility, from either an empirical or a theoretical point of view. Powell (1990) argued that firms conducting business in fast-moving industries with short product lifecycles often engage in network partnerships to reposition products rapidly and respond quickly to changing market conditions. Promoting the capabilities of manufacturers through the enhancement of supplier flexibility has become a critical aspect of the strategies employed by manufacturers. As noted previously, researchers have recently discovered that the selection of influence strategies and social capital have a significant influence on trading relationships (Boyle and Dwyer, 1995; Frazier and Rody, 1991; Gelderman et al., 2008; Kumar, 2005). Therefore, this study performed an empirical examination of the effects that influence strategies and social mechanisms (trust and shared vision) have on supplier flexibility. This paper also examines the effect of supplier flexibility on the performance of manufacturers.

We divided this paper into four sections. First, we review the literature on flexibility, influence strategies, social mechanisms, and performance for the presentation of a conceptual framework. Second, we illustrate the formulation of a specific hypothesis regarding potential antecedents and outcomes related to supplier flexibility and the performance of manufacturers. Third, the development and testing of these hypotheses is presented. Finally, the article includes a concluding summary of the research findings and implications of this study, followed by a discussion of the limitations, and directions for future research.

\section{Research framework and hypothesis}

Figure 1 provides a conceptual model summarizing our research interests and objectives. Based on the literature
Figure 1 Conceptual model

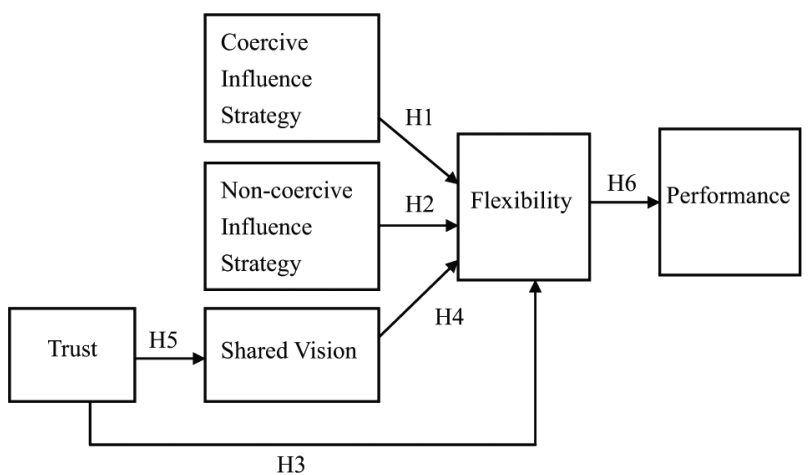

review, we generated six hypotheses associated with the model. These hypotheses focus on the interrelationships among influence strategies, social mechanisms, supplier flexibility, and the performance of manufacturers.

\subsection{Flexibility}

Gupta and Goyal (1989, p. 120) defined flexibility as: "the ability of a manufacturing system to cope with changing circumstances or instability caused by the environment." Environmental turbulence is the primary reason for seeking manufacturing flexibility (Corrêa, 1994). Zhang et al. (2003, p. 178) regarded manufacturing flexibility as " $t$ the ability of the organization to manage production resources and the uncertainty to meet various customer requests". Recently, market turbulence and technology turbulence have been forcing firms to respond quickly, while striving to gain future business opportunities. Upton (1995) described internal flexibility as the actions that firm are capable of performing (competencies) and external flexibility as the perceptions of customers regarding those actions (capabilities). External flexibility directly influences a firm's competitiveness; and internal flexibility relates to a firm's operational efficiency (Chang et al., 2003). To achieve a high degree of customer value (i.e. delivery on time, high-quality and low-cost), firms must look beyond their internal flexibility (Lummus et al., 2003; Zhang et al., 2002).

Slack (2005, p.1193) noted four distinct and important types of system flexibility. The response to environmental uncertainty is significantly related to the following examples of supplier flexibility:

1 Volume flexibility. The ability to change the level of aggregate output.

2 Mix flexibility. The ability to change the range of products produced within a given time period.

3 Product flexibility. The ability to introduce novel products, or to modify existing ones.

4 Delivery flexibility. The ability to alter planned or assumed delivery dates.

\subsection{Influence strategies}

In the literature on marketing, it is commonly mentioned that influence strategies are a means of communicating, in which a source firm attempts to gain compliance from target partners (Frazier and Summers, 1984). In the context of the supply chain, influence strategies refer to the content and structure of communications employed by a manufacturer to influence the 
attitudes and behavior of suppliers. Frazier and Summers (1984) provided taxonomy of influence strategies:

- Promises. The source offers specific rewards if the target conforms to the stated desires of the source.

- Threats. The source threatens the target with future negative sanctions if the target fails to comply with a request.

- Legalistic pleas. The source contends that legal contracts or agreements require the compliance of the target.

- Requests. The source simply asks the target to act without mentioning or directly implying subsequent sanctions, requests, or rewards.

- Information exchange. The source provides general information related to issues, to alter the target's perspectives without stating a request.

- Recommendations. The source describes how the target could benefit, if it achieves the specific desired outcomes.

Frazier and Summers (1986) categorized threats, legalistic pleas, and promises as coercive influence strategies; and classified requests, information exchange, and recommendations as non-coercive influence strategies. Within the context of the supply chain, coercive influence strategies refer to the direct pressure (e.g., rewards and punishments) a manufacturer puts on a supplier to perform a specific behavior by stressing the negative implications of noncompliance (Frazier and Rody, 1991). A threat is a tactic wherein a manufacturer states that failure to deliver a desired action will cause the supplier to lose future business opportunities. The legalistic pleas strategy involves a manufacturer citing obligations within the purchasing agreement to coerce suppliers to perform particular actions. A promise yields rewards (i.e. by price premiums, more orders), if the supplier complies with the manufacturer's requirements. If the supplier does not comply with the manufacturer's requirement, a depreciation of the reward could imply an imposition of sanctions (Gelderman et al., 2008).

Noncoercive strategies address the beliefs and attitudes of suppliers, with little direct pressure from the manufacturer. Molla and Sanchez (1997) pointed out that noncoercive strategies are the most common form of persuasion, according to a survey of computer manufacturers in Spain. Payan and McFarland (2005) speculated that manufacturers use noncoercive influence strategies (i.e., recommendations, information exchange, and requests) based on persuasion instead of coercion. In the context of manufacturer-supplier relationships, a request strategy is employed when a manufacturer states his desired actions to its supplier without mentioning any consequences related to compliance or noncompliance. The primary use of the information exchange strategy is to enhance communication on topics related to general strategy, such as cost reduction or product differentiation strategies. Previous studies have made the claim that the higher the degree of interdependence between the source and target, the more likely the source is to adopt a noncoercive influence strategy (Frazier and Summers, 1986; Frazier and Rody, 1991; Lai, 2008). Finally, the recommendation strategy is employed when a manufacturer describes how a particular set of actions would profit the supplier. For instance, a manufacturer could communicate with the suppliers that on-time delivery would be beneficial to future business.

Under conditions of changeable customer demands, a manufacturer not only adjusts its own capacity, but also needs its suppliers to meet the quantities demanded by the customer. An inability on the part of suppliers to match the manufacturer's requests for volume (i.e. volume flexibility) could lead to shortages in supply or a surplus in inventory. As for mix flexibility, a manufacturer requires of its suppliers the ability to produce multiple products at a particular capacity with the ability to implement rapid changeovers from one product to another in response to a variety of customer preferences. Koste and Malhotra (1999) proposed two dimensions of product flexibility that must be addressed: modification flexibility and new product flexibility. Manufacturers need to shorten the time required for the development of new products, particularly products with a short life cycle. Christopher (2000, p. 42) emphasized that "new product introduction time can be dramatically reduced through the involvement of suppliers in the innovation process." For example, if suppliers work closely with the manufacturer and provide technical or design support during the pre-launch stage of new products, the manufacturer could introduce a new product on time, or ahead of schedule. Additionally, a manufacturer does not only deliver on time, but also has the ability to change the planned delivery date (Sawhney, 2006). Delivery reliability refers to the ability to deliver on or before the promised scheduled due date (Handfield aand Pannesi, 1992). Delivery dependability refers to the ability to deliver the appropriate quantities of the required products on time (White, 1996). A high degree of delivery reliability and dependability on the part of suppliers enables manufacturers to easily adapt to customer needs. If the supplier lacks the ability to accommodate rush orders and deliver on the promised due date (Chan, 2003), it may create negative customer value for the manufacturer. Additionally, a manufacturer does not only deliver on time, but also has the ability to change planned delivery date (Sawhney, 2006). Delivery reliability refers to the ability to deliver on or before the promised scheduled due date (Handfield et al., 1992). However, delivery dependability refers to the ability deliver on time with accurate quantities and types of products needed (White, 1996). A supplier's delivery reliability and dependability enable the manufacturer to easily adapt to customer needs. If the supplier lacks the ability to accommodate rush orders and delivery on the promised due dates (Chan, 2003), it may create a negative customer value for the manufacturer.

Wathne and Heide (2004) argued that manufacturers often rely on operational strategies to influence the flexibility of suppliers. With dynamic customer needs and preferences, rapid technological advances, and fierce competition, a manufacturer could use coercive influence strategies to force suppliers to comply with its demands. For example, a manufacturer might threaten its suppliers by suggesting that a failure to deliver adjusted volumes could result a loss of future orders or the imposition of a price discount. In addition, a manufacturer might use obligations specified in the purchase agreement requiring suppliers to comply with adjustments to production volumes or delivery dates. A manufacturer might also reward (i.e. price premiums, increased business 
opportunities) suppliers in the event that they comply. In contrast, noncoercive strategies encourage suppliers to work with manufacturers to resolve problems (Frazier and Rody, 1991). A manufacturer might only state the actions it would like the supplier to take, without explicitly stating the consequences of compliance or noncompliance (i.e. request). The suggestions forwarded by the manufacturer could include a description of the potential benefits afforded by compliance (i.e. recommendation), or simply discuss general issues with the intent of motivating compliance (i.e. information exchange) (Frazier and Summers, 1986; Payan and McFarland, 2005). The intended use of noncoercive influence strategies is to alter supplier beliefs and attitudes to comply with the requirements of the manufacturer.

In summary, coercive influence strategies are high-pressure methods to elicit positive responses from suppliers by emphasizing the adverse consequences of noncompliance (Frazier and Rody, 1991). These strategies have clearer intentions than noncoercive methods. Beliefs and attitudes are the basis of noncoercive influence strategies helping suppliers to take desired actions, nurture healthy relationships, and increase economic and social satisfaction (Lai, 2007). Accommodating customer demands is a necessary condition for the survival of manufacturers. In response to dynamic customer demand, a manufacturer has a variety of influence strategies with which to manipulate suppliers to provide the flexibility required to satisfy customers. A manufacturer may use noncoercive influence strategies to change the attitudes of suppliers toward the intended behaviors (Frazier and Summers, 1984, 1986), or use coercive influence strategies to compel specific actions and promote flexibility:

H1. The use of coercive influence strategies by a manufacturer has a positive impact on supplier flexibility.

H2. The use of noncoercive influence strategies by a manufacturer has a positive impact on supplier flexibility.

\subsection{Social mechanisms}

This study focuses on trust and shared vision as two psychological bonding mechanisms influencing supplier flexibility.

\subsubsection{Trust}

The definition of trust used throughout this article is the belief in the reliability of a promise made by a partner to fulfill its obligations within the relationship (Schurr and Ozanne, 1985). Trust is a willingness to rely on an exchange partner in whom one has confidence (Moorman et al., 1992). Trust plays a more significant role in inter-organizational relationships because the degree of uncertainty and risk is higher (Dyer and Chu, 2003; Mayer et al., 1995; McEvily et al., 2003). In marketing literature, Anderson and Narus (1990, p. 45) defined trust, as:

[...] a belief that another company will perform actions resulting in positive outcomes for the firm, as well as an assurance that the other party will refrain from actions that would result in negative outcomes for the firm.

According to social exchange theory, prior interactions lead to the development of high levels of trust between parties. Das and Teng (1998, p. 496) argued that "trust building takes considerable resources from organizations over time". Creating trust involves reciprocation of beneficial actions through manifold interactions over time (Blau, 1964; Homans, 1958). Lambe et al. (2001) suggested that trust building between two parties could begin with relatively minor transactions, with the level of trust increasing as the number or size of the interactions increases.

The issue of trust in manufacturer-supplier relationships is very important because dyadic relationships often involve a high degree of interdependence. Zaheer et al. (1998) demonstrated that inter-organizational trust could reduce conflict among exchange partners as well as the cost associated with negotiation. Two types of trust are generally associated with manufacturer-supplier relationships: the manufacturer's trust in the supplier; and the supplier's trust in the manufacturer. The belief of the manufacturer in the willingness of suppliers to uphold their promises and their ability to provide quality products and services establishes a sense of trust felt by the manufacturer toward their suppliers. When manufacturers perceive suppliers as capable of providing quality products and services purchasing outcome becomes more predictable. In addition, a supplier's belief that manufacturers are acting in their best interest when making important decisions, and that promises made by manufacturers will be honored, establishes a sense of trust felt by the supplier toward the manufacturer. When suppliers perceive manufacturers as honest and benevolent, they show a willingness to provide quality goods and offer support in response to manufacturer demands for flexibility. According to the principle of reciprocity in exchange theory (Blau, 1964), "trust entails trust" (see McDonald, 1981). Therefore, this paper argues that the trust of suppliers in manufacturers is an important antecedent to the trust of manufacturers in suppliers (Gao et al., 2005). When the trust of a manufacturer relies on the trust of the supplier, an environment of trust must exist to maintain a stable and long-lasting relationship (Anderson and Weitz, 1992; Smith and Barclay, 1997). Therefore, this study chose to use the level of trust manufacturers feel for their suppliers as the element of trust in our manufacturer-supplier model.

When a positive relationship between a manufacturer and its suppliers is developed, this is an indication that the manufacturer is willing to collaborate in business relationships to achieve higher gains in the long run than they would by conducting discrete transactions in the short term. In addition, trust can facilitate inter-organizational communication and information sharing to improve responsiveness (Handfield and Bechtel, 2002). Trust increases the probability that the valuable manufacturersupplier relationship remains intact. The supplier has a greater motivation to increase the value delivered to the manufacturer by adapting its products, processes, and resources to the specific needs of the manufacturer. Therefore, a manufacturer's trust in its supplier positively influences supplier flexibility:

H3. A manufacturer's trust in its suppliers has a positive impact on supplier flexibility.

\subsubsection{Shared vision}

Shared vision is the degree of similarity between the shared values and beliefs ( $\mathrm{Li}$ and $\mathrm{Lin}, 2006$ ) held by two or more 
parties, and is a common mental model used to indicate the future state of the team (Pearce and Ensley, 2004). Hoe and McShane (2002, p. 283) indicated that "A shared vision is a clear, common, specific picture of a truly desired future state". Accordingly, shared vision provides exchange parties a sense of direction, and helps to bind together a loosely coupled system, thereby integrating strategic resources. Empirical studies have shown that parties in a supply chain with shared vision perform better (e.g., Spekman et al., 1999), while Boddy et al. (2000) determined that a lack of shared vision between suppliers and customer negatively influences cooperation. Without a shared vision between the manufacturer and supplier, exchange partners may promote their own interest, at the expense of their partners.

Manufacturers and suppliers expect a positive relationship between shared vision and the flexibility of suppliers, because shared vision between two parties in an exchange relationship facilitates meaningful communication. Firms sharing the same vision of the supply chain believe that their partners are on the same team and committed to mutual benefit. Developing shared vision between a manufacturer and supplier can help both parties to focus on strategies (Voss, 2005) aligning their actions toward a common goal. Miller et al. (2007) found that shared vision contributes to the business benefits perceived by members of the network. If both manufacturers and suppliers understand the importance of collaboration and improvement throughout the supply chain, they will engage in cooperative actions ( $\mathrm{Li}, 2005)$. Manufacturers and suppliers with a shared vision gain a wider perspective toward the long-term orientation (Ganesan, 1994; Lusch and Brown, 1996) with a sharper focus on achieving future goals. If suppliers clearly understand the mutual benefits to be derived from such interactions, they will take the actions necessary to meet the flexibility demands of the manufacturer. Therefore, this paper proposes the following hypothesis:

H4. Shared vision has a positive impact on supplier flexibility.

\subsubsection{Linking trust and shared vision}

Trust is the major manifestation of the relational dimension of social capital, and a major contributor to the development of shared vision. Manufacturers and suppliers expect a positive relationship between trust and shared vision because a trusting relationship implies that the manufacturer and suppliers would both benefit from better communication. Partners operating at a high level of trust are more willing to take risks, such as exchanging information that may be sensitive or confidential. The sharing of such information between partners facilitates a common understanding of collective goals and the development of a cohesive team environment. Trust is an essential element in supply chain relationships and a catalyst promoting solidarity. By displaying trust, parties develop a greater respect and mutual understanding of each other, enabling them to begin reaching toward a common goal. Trust is a prerequisite of shared vision. In other words, trust helps to convey a sense of identity in inter-organizational relationships and encourages commitment towards collective goals, helping to build a shared vision between organizations. Accordingly, this study proposes:
H5 (a). The trust of manufacturers in its suppliers leads to the development of a shared vision.

This study proposes that the trust a manufacturer has in its supplier influences supplier flexibility, resulting in enhanced manufacturer performance. In this manner, shared vision mediates the relationship between trust and supplier flexibility. As previously discussed, trust helps manufacturers and suppliers to develop mutual goals and realize the importance of cooperation in terms of a shared vision. Trust has positive social benefits drawing parties closer together by embedding a social framework promoting cooperation (Stinchcombe, 1986; Thibaut, 1968), and facilitating a common understanding of aims and objectives (Anderson and Weitz, 1989). When a manufacturer and its supplier connect socially, the willingness of the supplier to adapt to the needs of the manufacturer increases. This can be attributed to the common understanding of both parties regarding their aims and objectives, in recognition of joint interests. If suppliers have a clear understanding of the mutual benefits of their actions, they will take the necessary steps to meet the flexibility requirements of the manufacturers with whom they operate. The above arguments lead to:

$H 5$ (b). Shared vision mediates the relationship between the trust a manufacturer has in its suppliers and supplier flexibility.

\subsection{Relationship between supplier flexibility and manufacturer performance}

This study adopted the market performance of individual firms as the outcome variable of supplier flexibility. The dimensions of market performance in this study were growth in market shares, growth in sales, customer satisfaction, and new customer projects. The market performance of firms depends on the benefits to be obtained through supplier flexibility. The performance measures of a manufacturer should not only correspond to its strategic goals, but also to the goals and values of customers (Beamon, 1999). Manufacturers must take customer response into account. The level of satisfaction felt by customers is a reflection of the effectiveness of a manufacturer's actions, while market share and revenue reflect the growth domains of performance (Kaplan and Norton, 1996; Venkatraman and Ramanujam, 1986). The success of a new project represents the ability of the players to respond to a turbulent environment (Ruekert et al., 1985). Recent studies have emphasized inter-firm relationships as a means to acquire external resources (Stuart, 2000; Harrison et al., 2001). Providing the best product as well as the highest degree of satisfaction for the customer is the ultimate goal of manufacturers and their suppliers.

According to the resource-based view (RBV), a manufacturer uses rare, valuable, inimitable, and nonsubstitutable resources to ensure sustained competitive advantage (Barney, 1991). Based on the RBV, exploiting these resources and developing competitive advantage require that manufacturers obtain complementary resources from external sources. Responsiveness in the supply chain "elicits the dynamic nature of a firm's supply chain capabilities" (Wu et al., 2006, p. 495). A manufacturer is able to access the flexibility of its suppliers as a complementary resource to quickly respond to customer demands. Alternatively, if 
suppliers are able to provide flexibility to accommodate uncertainty in demand, then manufacturers could increase customer satisfaction, market share, sales growth, or the number of new projects. Drawing on the RBV of firms, this study argues that supplier flexibility can be employed as complementary resources leading directly to improved performance. Given the supplier flexibility described in previous sections, a manufacturer could increase performance by leveraging supplier flexibility. Therefore:

H6. The flexibility of suppliers positively influences manufacturer performance.

\subsection{Control variables}

Firm size is often believed to affect firm performance (Contractor et al., 2007; Ravenscraft, 1983). If a large manufacturer has more resources and power than suppliers do, it can lead to better performance. Industry effects played a central role in determining profitability (Hawawini et al., 2003; Schmalensee, 1985). Company strategies differ between industries. In the face of environmental turbulence, manufacturers in high-technology industries may prefer the use of coercive influence strategies to enforce compliance among suppliers. Influence strategies can vary between industries; therefore, control variables include the size of the manufacturer (measured by the total number of employees) and type of industry. These variables enable researchers to identify the nature of the relationship between supplier flexibility and manufacturer performance.

\section{Methodology}

\subsection{Sample and data collection}

A survey questionnaire was e-mailed to 1,000 members randomly selected from among the 5,000 members of the Supply Management Institute (SMIT, Taiwan, www.capm.or g.tw), an institute for purchasing management certification (e.g. Certified Purchasing Professional and Certified Purchasing Manager) training. A questionnaire was pretested with 25 middle and top purchasing managers from various companies not included in the final study. Based on their responses, several questions were eliminated and reworded. The revised survey questionnaires were sent out by e-mail to purchasing managers or executors of manufacturing firms, in charge of transactions with suppliers. Purchasing managers were selected because they often function as the main point of contact with suppliers. Participants were asked to select one important supply relationship and answer all questions by referring to this supplier. Two weeks after the initial mailing, we sent followup mail to non-respondents with a copy of the questionnaire, resulting in 175 returns out of 1,000 questionnaires (17.5 percent). After eliminating 13 incomplete questionnaires, a final sample of 162 questionnaires remained for analysis (16.2 percent). Rutner and Gibson (2001) reported an expected response rate of 5.7 percent from data collection through the "e-mail-out-e-mail return" method. In addition, their study on logistics information systems indicated that different survey techniques yielded different rates of return ranging from 3.7 percent to 12.6 percent. The return rate of this survey is considered acceptable for the e-mail survey method with supply chain targets. We compared the response group before and after the follow-up mail, showing no significant differences in terms of the number of employees $(t=0.985$, $p=0.328)$, or level of performance $(t=0.789, p=0.433)$. Table I presents characteristics of our final samples.

Since the data of this study were gathered from a single respondent, there is the possibility for the occurrence of common method bias. We used a Harmon's one-factor analysis to check for common method bias (Podsakoff and Organ, 1986). If common method variance is a serious problem in this study, a single factor will emerge from a factor analysis or one general factor accounts for most of the covariance (Podsakoff and Organ, 1986). An exploratory factor analysis found many factors derived and explained 71.15 percent of the variance, while a single factor explained only 19.32 percent of the variance. Therefore, common method bias is not a significant problem in our data (Podsakoff et al., 2003). Social desirability bias in surveys has been found to be important. When respondents respond to socially sensitive questions, or fear expressing socially undesirable attitudes (King and Bruner, 2000), socially desirable bias is most likely to occur. As Nederhof (1985) suggested, self-administration of the questionnaire can prevent or reduce social desirability bias. A self-administered questionnaire was e-mailed to these subjects along with a covering letter providing information about purpose of the survey. Thus, socially desirable bias is not of great concern in this study.

\subsection{Measures}

The measurements for each construct in this study are listed in the Appendix, Table AI. Informants responded to a fivepoint Likert-type scale for all variables from "strongly disagree" (1) to "strongly agree" (5).

\subsubsection{Flexibility}

With regard to flexibility, the measurements of volume and mix flexibility were modified from Zhang et al. (2003). This included five items for the measurement of volume flexibility and six items for mix flexibility. With respect to delivery flexibility and product flexibility, we modified the

Table I Characteristics of informants' firms

\begin{tabular}{lcc}
\hline Characteristics & $\begin{array}{c}\text { Number in } \\
\text { sample }\end{array}$ & Percentage \\
\hline $\begin{array}{l}\text { Industry } \\
\text { High-tech manufacturing }\end{array}$ & 82 & 50.62 \\
Traditional manufacturing & 80 & 49.38 \\
Number of employees & & \\
$<1,000$ & 94 & 58.02 \\
$>1,000$ & 68 & 41.98 \\
Relation duration with supplier (years) & & \\
$<3$ & 9 & 5.56 \\
3 to 5 & 17 & 10.49 \\
6 to 10 & 57 & 35.19 \\
$>10$ & 78 & 48.15 \\
Not reported & 1 & 0.62 \\
Relation type & & \\
Purchasing & 98 & 60.49 \\
Outsourcing & 18 & 11.11 \\
Both & 46 & 28.40 \\
\hline
\end{tabular}


measurements in reference to related studies (see Chan, 2003; Duclos et al., 2003; D'Souza and Williams, 2000; Krause et al., 2001; Koste and Malhotra, 1999; Sawhney, 2006). The questionnaire included five items for the measurement of delivery flexibility and four items for product flexibility.

\subsubsection{Influence strategies}

A modified version of the outlined influence strategies developed by Boyle et al. (1992) was employed in this study. Addressing the issue of coercive influence strategies (COR), informants were asked about the extent to which the manufacturer used promises, threats, and legalistic pleas or noncoercive strategies (NCOR) such as recommendations, requests, and the exchange of information. One item related to legalistic pleas was deleted because pretest respondents felt the item was an inappropriate measure. Thus, the questionnaire included 15 items related to the subscale of coercive strategies and 12 items for noncoercive strategies.

\subsubsection{Trust and shared vision}

To examine the effect of trust and shared vision (SHV), we employed constructs from prior studies (e.g. trust taken from Kumar et al., 1995; Kozak and Cohen, 1997; Spekman et al., 1999 and shared vision from $\mathrm{Li}$ and Lin, 2006), employing nine items for trust and three items for shared vision.

\subsubsection{Performance}

The measurement of performance was adopted from Vorhies et al. (1999). This included four items for the measurement of performance including growth in market share, growth in sales, customer satisfaction, and the introduction of new products related to those produced by major competitors.

\subsubsection{Control variable}

We controlled for several potential sources of heterogeneity in our sample. Firm size (Contractor et al., 2007: Ravenscraft, 1983) and industry type (Hawawini et al., 2003; Schmalensee, 1985) are likely to influence the performance of firms. All control variables were measured using dummy variables Firm size was measured by employee headcounts 1 - more than 1,000 and $0-$ less than 1,000 . With regard to industry type (IND) measurement, 1 represented high-tech firms and 0 represented traditional manufacturing firms.

\subsection{Reliability and validity}

The reliability of all scales exceeded the following criteria: Cronbach's alpha was greater than the 0.60 cutoff (Sakakibara et al., 1997), composite reliability (CR) was greater than the 0.70 cutoff (Fornell and Larcker, 1981), and average variance extracted (AVE) was greater than the 0.50 cutoff (Anderson and Gerbing, 1988; Fornell and Larcker, 1981; Hair et al., 1998). All variables were successfully measured, with the summary of statistics and correlation matrix are presented in Table II.

We tested the validity of the construct measures through confirmatory factor analysis of all first-order constructs. Sixfactor (recommendation, information exchange, request, legalistic pleas, promise, and threat), four-factor (mix, delivery, product, and volume flexibility) and three-factor (trust, shared vision, and performance) confirmatory factor analyses were used to estimate the goodness-of-fit. The fit of the model exceeded the standard cutoffs for acceptable fit: influence strategies $\quad\left(\chi^{2}(156)=191.7, \quad p<0.05\right.$; RMSEA $=0.038 ; \quad$ RMR $=0.044 ; \quad$ CFI $=0.978$;
TLI $=0.970), \quad$ flexibility $\quad\left(\chi^{2}(73)=91.73, \quad p>0.05\right.$; $\mathrm{RMSEA}=0.04 ; \mathrm{RMR}=0.025 ; \mathrm{CFI}=0.984 ; \mathrm{TLI}=0.977)$ and trust, shared vision and performance $\left(\chi^{2}(31)=39.11\right.$, $p>0.05 ; \quad \mathrm{RMSEA}=0.04 ; \quad \mathrm{RMR}=0.02 ; \quad \mathrm{CFI}=0.992 ;$ $\mathrm{TLI}=0.989$ ). From the result of CFA factor loadings, the magnitudes of the factor loadings and levels of statistical significance provided evidence of the convergent validity of the measures. To further assess the validity of flexibilities as a second-order construct, this research further conducted a second-order CFA to examine the underlying unidimensionality of flexibility constructs and influence strategies. For flexibility $\left(\chi^{2}(76)=92.81, \quad p>0.05\right.$; RMSEA $=0.037 ; \quad \mathrm{RMR}=0.025 ; \quad \mathrm{CFI}=0.986$; $\mathrm{NFI}=0.927 ; \quad \mathrm{GFI}=0.931) . \quad$ For influence strategies $\left(\chi^{2}(136)=161.04, \quad p>0.05 ; \quad \mathrm{RMSEA}=0.034 ;\right.$ $\mathrm{RMR}=0.053 ; \mathrm{CFI}=0.984 ; \mathrm{NFI}=0.907 ; \quad \mathrm{GFI}=0.915)$. We measured the efficacy of the two models by comparing 2 statistics of the first-order model and the second-order model (Marsh and Hocevar, 1985). The second-order CFA supported the view of flexibility as a single overall construct composed of four distinct sub-dimensions. The results of second-order CFA on influence strategies also provided additional evidence to support influence strategies was modeled as a second-order construct (i.e. coercive and noncoercive strategies). Finally, we used the average variance extracted (AVE) exceeding 0.5 as the criterion to assess discriminant validity (Fornell and Larcker, 1981). Table II also shows that all AVE exceeded the squared correlation between any pair of constructs, thereby supporting a satisfactory level of discriminant validity. In Table II, we report the means, standard deviation, and zero-order correlations of our variables.

\section{Results}

To test the hypothesized relationships, we conducted regression analysis, the results of which are presented in Table III. The structural equation modeling (SEM) was not conducted since there were nonmetric control variables in our study. If SEM is conducted, the nominal scale variables should be modified to continuous measurement (Skrondal and Rabe-Hesketh, 2005). To check for potential multicollinearity, we assessed the variance inflation factors (VIFs) associated with each of the predictors in our models. The value of the VIFs remained below the 10.0 benchmark, for no indication of severe multicollinearity. The DurbinWatson test was employed to test the autocorrelation. The result of Durbin-Watson test statistic (2.031) indicated no presence of autocorrelation. In addition, the Levene's Test for homogeneity of variances was conducted. The results showed assumption of equal variances was accepted. For H1, coercive influence strategy has a significant positive effect on suppliers' flexibility. Results for Model 1 in Table III indicate support for this hypothesis $(\beta=0.290, p<0.001)$. H2 predicted that noncoercive influence strategies have a significant positive effect on suppliers' flexibility. The standardized coefficient of noncoercive influence strategy was negative but not statistically significant $(\beta=-0.043, \quad p>0.1)$. The prediction of $H 3$ was not supported $(\beta=0.073, p>0.1)$, based on the fact that trust does not have a significantly positive effect on supplier flexibility. The prediction of $H 4$ in 
Table II Correlation matrix and summary statistics

\begin{tabular}{|c|c|c|c|c|c|c|}
\hline Variables & 1 & 2 & 3 & 4 & 5 & 6 \\
\hline 1. Performance & 1.00 & & & & & \\
\hline 2. Flexibility & $0.225^{* *}$ & 1.00 & & & & \\
\hline 3. SHV & 0.117 & $0.417^{* *}$ & 1.00 & & & \\
\hline 4. Trust & 0.026 & $0.241 * *$ & $0.428 * *$ & 1.00 & & \\
\hline 5. COR & 0.103 & $0.326 * *$ & 0.087 & 0.074 & 1.00 & \\
\hline 6. NCOR & -0.11 & $0.176^{*}$ & $0.225 * *$ & 0.143 & $0.394^{* *}$ & 1.00 \\
\hline Means & 3.833 & 3.703 & 4.008 & 3.627 & 3.380 & 3.431 \\
\hline Standard deviation & 0.730 & 0.459 & 0.640 & 0.512 & 0.493 & 0.412 \\
\hline Composite reliability & 0.855 & 0.945 & 0.935 & 0.885 & 0.930 & 0.933 \\
\hline AVE & 0.599 & 0.537 & 0.827 & 0.721 & 0.528 & 0.612 \\
\hline
\end{tabular}

Notes: *Correlation is significant at the 0.01 level (two-tailed); ${ }^{*}$ correlation is significant at the 0.05 level (two-tailed)

Table III Regression result with respect to flexibility and performance

\begin{tabular}{|c|c|c|c|c|c|c|}
\hline \multirow[b]{2}{*}{ Dependent variable } & \multicolumn{2}{|c|}{$\begin{array}{l}\text { Flexibility } \\
\text { (Model 1) }\end{array}$} & \multicolumn{2}{|c|}{$\begin{array}{l}\text { Performance } \\
\text { (Model 2) }\end{array}$} & \multicolumn{2}{|c|}{$\begin{array}{c}\text { Performance } \\
\text { (Model 3) }\end{array}$} \\
\hline & Standardized $\boldsymbol{\beta}$ & $t$-value & Standardized $\boldsymbol{\beta}$ & $t$-value & Standardized $\boldsymbol{\beta}$ & $t$-value \\
\hline \multicolumn{7}{|l|}{ Controls } \\
\hline Size & -0.065 & -0.874 & 0.052 & 0.637 & 0.103 & 1.330 \\
\hline IND & $0.157^{* *}$ & 2.200 & $0.221 * * *$ & 2.794 & $0.199 * *$ & 2.575 \\
\hline \multicolumn{7}{|l|}{ Predictors } \\
\hline COR & $0.290 * * *$ & 3.758 & 0.105 & 1.195 & & \\
\hline NCOR & -0.043 & -0.554 & $-0.204 * *$ & -2.389 & & \\
\hline Trust & 0.077 & 1.003 & -0.010 & -0.117 & & \\
\hline SHV & $0.393 * * *$ & 5.084 & 0.094 & 1.032 & & \\
\hline Flexibility & & & $0.167^{*}$ & 1.903 & $0.198 * * *$ & 2.616 \\
\hline$R^{2}$ & 0.278 & & 0.145 & & 0.112 & \\
\hline Adjusted $R^{2}$ & 0.250 & & 0.107 & & 0.095 & \\
\hline F-statistic & $9.966 * * *$ & & $3.742 * * *$ & & $6.617^{* * *}$ & \\
\hline
\end{tabular}

which shared vision has a significantly positive effect on supplier flexibility $(\beta=0.393, p>0.001)$ was supported. In Model 2, the effect of supplier flexibility on performance outcome $(\beta=0.167, p>0.1)$ was positive and significant. Hence, the result supports H6. From Model 2, the effect of supplier flexibility on manufacturer performance was statistically significant at 0.1 level. We further conducted the direct effect of supplier flexibility on performance. In Model 3 , the standardized coefficient $(\beta=0.198, p>0.01)$ indicated that supplier flexibility has a significantly positive effect on manufacturer performance. Additionally, the effect of noncoercive influence strategies on performance showed negatively significant in Model 2. According to Payan and McFarland (2005), the use of noncoercive influence strategies (i.e. recommendation) had a negative effect on compliance. Our finding indicated that noncoercive influence strategies have a negative effect on manufacturer performance. The possible explanation is the effect of noncoercive influence strategies takes more time and lacks of specificity of argument about the target. Thus, the use of noncoercive influence strategies may reduce the performance outcome of manufacturer. Moreover, to assess the mediation effect of manufacturer trust on the relationship between shared vision and supplier flexibility, we applied the mediated regression procedure outlined by Baron and Kenny (1986) (see Table IV). First, as shown in Model 4, trust relates positively to shared vision $(\beta=0.418, p>0.001)$ supporting $H 5(a)$. Second, as shown in Model 5 , the statistically significant beta of trust on flexibility $(\beta=0.249, p>0.001)$ indicates that the condition of independent variables related to dependent variables was met. Third, as shown in Model 6, the direct effect of trust on flexibility was added to the original model, including the indirect effects, as mediated by shared vision. The result reveal that all of the direct effects of trust on flexibility were not significant $(\beta=0.082, p>0.1)$, and that shared vision has a significantly positive effect on supplier flexibility $(\beta=0.398, p>0.001)$. Therefore, we conclude that the effect of trust on flexibility is mediated by shared vision (Baron and Kenny, 1986; Venkatraman, 1989). H5(b) is supported. Finally, using firm size as the control variable revealed no significant effect on flexibility. Industry revealed a positive relationship between supplier flexibility and performance; however, this indicates that industry, as a control variable, did not influence the results of our findings. 
Table IV Mediated regression analysis

\begin{tabular}{|c|c|c|c|c|c|c|}
\hline \multirow[b]{2}{*}{ Dependent variable } & \multicolumn{2}{|c|}{$\begin{array}{c}\text { SHV } \\
\text { (Model 4) }\end{array}$} & \multicolumn{2}{|c|}{$\begin{array}{l}\text { Flexibility } \\
\text { (Model 5) }\end{array}$} & \multicolumn{2}{|c|}{$\begin{array}{l}\text { Flexibility } \\
\text { (Model 6) }\end{array}$} \\
\hline & Standardized $\boldsymbol{\beta}$ & $t$-value & Standardized $\boldsymbol{\beta}$ & $t$-value & Standardized $\boldsymbol{\beta}$ & $t$-value \\
\hline \multicolumn{7}{|l|}{ Controls } \\
\hline Size & 0.073 & 0.982 & 0.145 & 1.826 & 0 & -0.012 \\
\hline IND & -0.021 & -0.287 & 0.028 & 0.356 & $0.154^{*}$ & 2.078 \\
\hline \multicolumn{7}{|l|}{ Predictors } \\
\hline Trust & $0.418 * *$ & 5.721 & $0.249 * *$ & 3.197 & 0.082 & 1.036 \\
\hline SHV & & & & & $0.398 * *$ & 5.05 \\
\hline$R^{2}$ & 0.188 & & 0.078 & & 0.207 & \\
\hline Adjusted $R^{2}$ & 0.173 & & 0.060 & & 0.187 & \\
\hline F-statistic & $12.215^{* *}$ & & $4.448 * *$ & & $10.228 * *$ & \\
\hline
\end{tabular}

\section{Conclusion and implications}

The results of this research provide important information for marketers engaged in the process of managing supplier flexibility. A customer-oriented manufacturer should have the ability to influence supplier flexibility to match dynamic customer demands. The manufacturer teams up with its suppliers to establish a long-term, cooperative relationship to establish a sustainable and competitive supply chain. Our study found that shared vision is the most important factor influencing supplier flexibility. Shared vision can help facilitate group actions benefiting the entire supply chain and promoting the flexibility of suppliers. Furthermore, the results of this study suggest the manufacturers are able to influence supplier flexibility to meet customer requirements by selecting coercive influence strategies.

\subsection{Influence strategies and supplier flexibility}

A manufacturer needs to meet customer requirements without adding significant cost (Gilmore and Pine, 1997). Supplier flexibility represents a manufacturer's ability to combine resources to serve customers. Coercive strategies are high-pressure attempts to influence suppliers to and elicit a desired response. Studies have revealed that manufacturers adopt coercive strategies in situations in which their advantage is unlikely to be diminished (Kale, 1986; Frazier et al., 1989). This research shows that manufacturers adopt coercive strategies when they need suppliers to be more flexible.

On the contrary, noncoercive strategies often refer to the means by which relationalism is promoted in exchanges (Boyle et al., 1992). Noncoercive strategies center primarily on the beliefs and attitudes of the target firm involving little direct pressure from the source firm. The effectiveness of noncoercive strategies requires considerable time to be realized (Frazier and Summers, 1984). Unlike coercive influence strategies, noncoercive strategies are noncompulsory, and therefore cannot force suppliers to comply with the requirements of manufacturers. Our findings suggest that noncoercive strategies are ineffective in improving supplier flexibility.

\subsection{Social mechanisms and suppliers' flexibility}

This study demonstrated that shared vision positively influences supplier flexibility, but trust does not. A possible explanation for this was that cultural differences may be particularly influential in this study. Hofstede (1980, p. 47) described a collectivist culture in terms of, "emphasis is on belonging to organizations; a membership is the ideal". According to Hofstede (1984) and Merritt (2000), Taiwan exhibits a highly collectivistic culture. The Taiwanese people view themselves as inherently interdependent within the group to which they belong. In collectivistic cultures, there is greater emphasis on meeting a shared vision to maintain harmony in one's relationship to the group. One might expect the group to easily achieve their collective goals in highly collectivistic norms. Another possible explanation appoints to shared vision as a key mediator between trust and the supplier flexibility. Because the manufacturer and supplier are separate firms with individual interest and goals (Iyer and Bergen, 1997), it is not certain the suppliers will comply with manufacturers' requests. In addition, Wathne and Heide (2004) argued that the opportunistic actions of a supplier may undermine the manufacturer's strategy. They also indicated that manufacturers must deploy specific governing mechanisms to mitigate potential opportunism. With regard to trust, Morgan and Hunt (1994) argued that trust builds confidence in the reliability and integrity of exchange partners. However, Das and Teng (1998) defined trust as a positive expectation concerning the motives of a target, with no influence on the behavior of a target. This study revealed that trust is effective in building a shared vision. If a manufacturer perceives suppliers as trustworthy, they will tend to share more sensitive or important information with them. Shared vision indicates that manufacturers and suppliers have similar objectives and a shared understanding of the importance of collaboration. Tsai and Ghoshal (1998, p. 467) described "shared vision as a bonding mechanism helping different sections of an organization to integrate or combine resources". Considering the ever-changing environment and need for quick responses to dynamic customer demands, shared vision is a prerequisite of supply chain partnerships. A supplier attempting to meet a manufacturer's needs may need to adjust its capacity and production plans. In this case, a supplier with limited capacity may be at risk of losing other business opportunities. With shared vision, the manufacturer and its suppliers feel like a team and understand that their goals are cooperative (Wong et al., 2005). Shared vision becomes a governing mechanism 
for promoting the interests of the entire supply chain $(\mathrm{Li}$, 2005).

Shared vision implies a stronger inter-organizational cohesiveness, increasing communication between the manufacturer and suppliers (Hoe and McShane, 2002). Frequent communication and interaction can help develop common goals and mutual understanding. To achieve the flexibility required in an unpredictable supply chain, manufacturers and suppliers need to incorporate high levels of cooperation and joint planning. In addition, the promotion of supplier flexibility may require an increase in investment or involvement (e.g. well-training workers, R\&D expenditures, capacity expansion). Therefore, suppliers with a shared vision consider the benefits of the entire supply chain and make more of an effort to comply with the manufacturer's demand for increased flexibility. This study also provides important implications for marketers that shared vision is the critical determinant to make suppliers more flexible. We would suggest that marketers need to evolve shared vision between interfirms rather than buying-selling approach.

\subsection{Suppliers' flexibility and manufacturers' performance}

Greater supplier flexibility gives manufacturers the advantage of responsiveness over their competitors. Suppliers with the ability to quickly change their production quantities (i.e. volume flexibility), simultaneously produce multiple products or changeover quickly from one product to another (i.e. mix flexibility) are far better able to compete. In addition, these suppliers can accommodate rush orders or special orders (i.e. delivery flexibility), reduce the time required to modify existing products, introduce new products (i.e. product flexibility), and are more likely contribute to the manufacturer's response to dynamic customer demands. Suppliers often limit the ability of a manufacturer to respond quickly to customer requirements (Christopher, 2000). However, the results of this study suggest that a manufacturer using a coercive influence strategy or building a shared vision with its suppliers can help to advance supplier flexibility to accommodate dynamic customer demands. This enables the manufacturer to perform better in terms of market share, sales revenue, customer satisfaction, and the solicitation of projects.

\section{Limitations and further research}

Future research could address several limitations of this study. First, this research design was cross-sectional in nature. Although a theoretical foundation and logic were the basis of the study model, making purely causal conclusions remained difficult. The need for evidence of causality from a longitudinal and/or experimental study remains. Second, the data gathered for this study relied on the perceptions of manufacturers regarding influence strategies and social mechanisms. Further research could explore the degree to which perceptions of influence strategies and social mechanisms are shared across the dyad. Third, the taxonomy of influence strategies studied in this paper was derived and incorporated from previous studies. The findings of this study indicate that coercive influence strategies play a significant role in supplier flexibility; however, this article did not address the effect of individual coercive influence strategies on flexibility. Gelderman et al. (2008) illustrated the importance of the sequence of coercive influence strategies arguing that dominant suppliers select distinct strategies from promises, threats, and legal pleas, in that order. Future research could concentrate in greater detail on the effect of distinct influence strategy sequences. Fourth, this study evaluated the performance in the growth and customer response domain. Future studies could attempt to integrate financial measurements (e.g. Profitability, Return on Assets) to validate the results. Fifth, Lusch and Brown (1996) found that a high bilateral dependency between partners leads to a heavy reliance on normative contracts (i.e. mutual understanding of the role played by each actor). A study of the relationships among the level of manufacturer-supplier interdependence, social mechanisms, and influence strategy deserves consideration. Finally, from the perspective of reciprocal action theory, the manufacturer should consider the dyadic interplay of influence strategies (Kim, 2000). The coercive or noncoercive influence strategies employed by manufacturers could stimulate the use of the same strategies by the dyadic exchange partner. How would the reciprocal strategies employed by a supplier influence the effectiveness of a manufacturer's influence strategies? Theoretically intriguing and practical questions such as this deserve further study.

\section{References}

Anderson, E. and Weitz, B. (1989), "Determinants of continuity in conventional industrial channel dyads", Marketing Science, Vol. 8 No. 4, pp. 310-23.

Anderson, E. and Weitz, B. (1992), "The use of pledges to build and sustain commitment in distribution channels", Fournal of Marketing Research, Vol. 29 No. 1, pp. 18-34.

Anderson, J.C. and Gerbing, D.W. (1988), "Structural equation modeling in practice: a review and recommended two-step approach", Psychological Bulletin, Vol. 103 No. 3, pp. 411-23.

Anderson, J.C. and Narus, J.A. (1990), "A model of distributor firm and manufacturer firm working partnerships", Fournal of Marketing, Vol. 54 No. 1, pp. 42-58.

Barney, J.B. (1991), "Firm resources and sustained competitive advantage", fournal of Management, Vol. 17 No. 1, pp. 99-120.

Baron, R.M. and Kenny, D.A. (1986), "The moderatormediator variable distinction in social psychological research: conceptual, strategic, and statistical considerations", Fournal of Personality and Social Psychology, Vol. 51 No. 6, pp. 1173-82.

Beamon, B.M. (1999), "Measuring supply chain performance", International Fournal of Operations E Production Management, Vol. 19 No. 3, pp. 275-92.

Blau, P.M. (1964), Exchange and Power in Social Life, Wiley, New York, NY.

Boddy, D., Macbeth, D. and Wagner, B. (2000), "Implementing collaboration between organizations: an empirical study of supply chain partnering", fournal of Management Studies, Vol. 37 No. 7, pp. 1003-18.

Boyle, B.A. and Dwyer, F.R. (1995), "Power, bureaucracy, influence, and performance: their relationships in industrial 
distribution channels", Fournal of Business Research, Vol. 32 No. 3, pp. 189-200.

Boyle, B., Dwyer, F.R., Robicheaux, R.A. and Simpson, J.T. (1992), "Influence strategies in marketing channels: measures and use in different relationship structures", Fournal of Marketing Research, Vol. 29 No. 4, pp. 462-73.

Chan, F.T.S. (2003), "Performance measurement in a supply chain", The International fournal of Advanced Manufacturing Technology, Vol. 21 No. 7, pp. 534-48.

Chang, S.C., Yang, C.L., Cheng, H.C. and Sheu, C. (2003), "Manufacturing flexibility and business strategy: an empirical study of small and medium sized firms", International fournal of Production Economics, Vol. 83 No. 1, pp. 13-26.

Christopher, M. (2000), "The agile supply chain: competing in volatile markets", Industrial Marketing Management, Vol. 29 No. 1, pp. 37-44.

Contractor, F.J., Kumar, V. and Kundu, S.K. (2007), "Nature of the relationship between international expansion and performance: the case of emerging market firms", Fournal of World Business, Vol. 42 No. 4, pp. 401-17.

Corrêa, H.L. (1994), Linking Flexibility, Uncertainty and Variability in Manufacturing Systems: Managing Unplanned Change in the Automotive Industry, Avebury, Aldershot.

D'Souza, D.E. and Williams, F.P. (2000), "Toward a taxonomy of manufacturing flexibility dimensions", Fournal of Operations Management, Vol. 18 No. 5, pp. 577-93.

Das, T.K. and Teng, B.S. (1998), "Between trust and control: developing confidence in partner cooperation in alliances", The Academy of Management Review, Vol. 23 No. 3, pp. 491-512.

Dirks, K.T. and Ferrin, D.L. (2001), "The role of trust in organizational settings", Organization Science, Vol. 12 No. 4, pp. 450-67.

Duclos, L.K., Vokurka, R.J. and Lummus, R.R. (2003), "A conceptual model of supply chain flexibility", Industrial Management and Data Systems, Vol. 103 No. 6, pp. 446-56.

Dyer, J.H. and Chu, W. (2003), "The role of trustworthiness in reducing transaction costs and improving performance: empirical evidence from the United States, Japan, and Korea", Organization Science, Vol. 14 No. 1, pp. 57-68.

Fornell, C. and Larcker, D.F. (1981), "Evaluating structural equation models with unobservable variables and measurement error", fournal of Marketing Research, Vol. 18 No. 1, pp. 39-50.

Frazier, G.L. and Rody, R.C. (1991), "The use of influence strategies in interfirm relationships in industrial product channels", fournal of Marketing, Vol. 55, January, pp. 52-69.

Frazier, G.L. and Summers, J.O. (1984), "Interfirm influence strategies and their application within distribution channels", fournal of Marketing, Vol. 48 No. 3, pp. 43-55.

Frazier, G.L. and Summers, J.O. (1986), "Perceptions of interfirm power and its use within a franchise channel of distribution", fournal of Marketing Research, Vol. 23 No. 2, pp. 169-76.

Frazier, G.L., Gill, J.D. and Kale, S.H. (1989), "Dealer dependence levels and reciprocal actions in a channel of distribution in a developing country", fournal of Marketing, Vol. 53 No. 1, pp. 50-69.
Ganesan, S. (1994), "Determinants of long-term orientation in buyer-seller relationships", fournal of Marketing, Vol. 58 No. 2, pp. 1-19.

Gao, T., Sirgy, M.J. and Bird, M.M. (2005), "Reducing buyer decision-making uncertainty in organizational purchasing: can supplier trust, commitment, and dependence help?", Fournal of Business Research, Vol. 58 No. 4, pp. 397-405.

Gelderman, C.J., Semeijn, J. and De Zoete, R. (2008), "The use of coercive influence strategies by dominant suppliers", Fournal of Purchasing and Supply Management, Vol. 14 No. 4, pp. 220-9.

Gilmore, J.H. and Pine, B.J. (1997), "The four faces of mass customization", Harvard Business Review, Vol. 75 No. 1, pp. 91-101.

Giunipero, L.C., Denslow, D. and Eltantawy, R. (2005), "Purchasing/supply chain management flexibility: moving to an entrepreneurial skill set", Industrial Marketing Management, Vol. 34 No. 6, pp. 602-13.

Gulati, R., Nohria, N. and Zaheer, A. (2000), "Strategic networks”, Strategic Management fournal, Vol. 21 No. 3, pp. 203-15.

Gupta, Y.P. and Goyal, S. (1989), "Flexibility of manufacturing systems: concepts and measurements", European fournal of Operational Research, Vol. 43 No. 2, pp. 119-35.

Hair, J.F., Anderson, R.E., Tatham, R.L. and Black, W.C. (1998), Multivariate Data Analysis, Prentice Hall, Upper Saddle River, NJ.

Handfield, R.B. and Bechtel, C. (2002), "The role of trust and relationship structure in improving supply chain responsiveness", Industrial Marketing Management, Vol. 31 No. 4, pp. 367-82.

Handfield, R.B. and Pannesi, R.T. (1992), "An empirical study of delivery speed and reliability", International fournal of Operations E Production Management, Vol. 12 No. 2, pp. 58-72.

Harrison, J.S., Hitt, M.A., Hoskisson, R.E. and Ireland, R.D. (2001), "Resource complementarity in business combinations: extending the logic to organizational alliances", fournal of Management, Vol. 27 No. 6, pp. 679-90.

Hawawini, G., Subramanian, V. and Verdin, P. (2003), "Is performance driven by industry or firm specific factors? A new look at the evidence", Strategic Management fournal, Vol. 24 No. 1, pp. 1-16.

Hoe, S.L. and McShane, S.L. (2002), "Leadership antecedents of informal knowledge acquisition and dissemination", International fournal of Organisational Behaviour, Vol. 5 No. 10, pp. 282-91.

Hofstede, G.H. (1980), "Motivation, leadership, and organization: do American theories apply abroad?", Organizational Dynamics, Vol. 9 No. 1, pp. 42-63.

Hofstede, G.H. (1984), Culture's Consequences: International Differences in Work-related Values, Sage Publications, Beverly Hills, CA.

Homans, G.C. (1958), "Social behavior as exchange", American fournal of Sociology, Vol. 63 No. 6, pp. 597-606.

Ivens, B.S. (2005), "Flexibility in industrial service relationships: the construct, antecedents, and performance outcomes”, Industrial Marketing Management, Vol. 34 No. 6, pp. 566-76. 
Iyer, A.V. and Bergen, M.E. (1997), "Quick response in manufacturer-retailer channels", Management Science, Vol. 43 No. 4, pp. 559-70.

Kale, S.H. (1986), "Dealer perceptions of manufacturer power and influence strategies in a developing country", Fournal of Marketing Research, Vol. 23 No. 4, pp. 387-93.

Kaplan, R.S. and Norton, D.P. (1996), "Using the balanced scorecard as a strategic management system", Harvard Business Review, Vol. 74, pp. 75-87.

Kim, K. (2000), "On interfirm power, channel climate, and solidarity in industrial distributor-supplier dyads", fournal of the Academy of Marketing Science, Vol. 28 No. 3, pp. 388-405.

King, M. and Bruner, G. (2000), "Social desirability bias: a neglected aspect of validity testing", Psychology and Marketing, Vol. 17 No. 2, pp. 79-103.

Koste, L.L. and Malhotra, M.K. (1999), "A theoretical framework for analyzing the dimensions of manufacturing flexibility", fournal of Operations Management, Vol. 18 No. 1, pp. 75-93.

Kozak, R.A. and Cohen, D.H. (1997), "Distributor-supplier partnering relationships: a case in trust", fournal of Business Research, Vol. 39 No. 1, pp. 33-8.

Krause, D.R., Pagell, M. and Curkovic, S. (2001), "Toward a measure of competitive priorities for purchasing", fournal of Operations Management, Vol. 19 No. 4, pp. 497-512.

Kumar, N. (2005), "The power of power in supplier-retailer relationships", Industrial Marketing Management, Vol. 34 No. 8, pp. 863-6.

Kumar, N., Scheer, L.K. and Steenkamp, J-B.E.M. (1995), "The effects of perceived interdependence on dealer attitudes", Fournal of Marketing Research, Vol. 32 No. 3, pp. 348-56.

Lai, C.S. (2007), "The effects of influence strategies on dealer satisfaction and performance in Taiwan's motor industry", Industrial Marketing Management, Vol. 36 No. 4, pp. 518-27.

Lai, C.S. (2009), "The use of influence strategies in interdependent relationship: the moderating role of shared norms and values", Industrial Marketing Management, Vol. 38 No. 4, pp. 426-32.

Lambe, C.J., Wittmann, C.M. and Spekman, R.E. (2001), "Social exchange theory and research on business-tobusiness relational exchange", fournal of Business to Business Marketing, Vol. 8 No. 3, pp. 1-36.

Li, L. (2005), "The effects of trust and shared vision on inward knowledge transfer in subsidiaries' intra- and interorganizational relationships", International Business Review, Vol. 14 No. 1, pp. 77-95.

Li, S. and Lin, B. (2006), "Accessing information sharing and information quality in supply chain management", Decision Support Systems, Vol. 42 No. 3, pp. 1641-56.

Lummus, R.R., Duclos, L.K. and Vokurka, R.J. (2003), "Supply chain flexibility: building a new model", Global fournal of Flexible Systems Management, Vol. 4 No. 4, pp. 1-13.

Lusch, R.F. and Brown, J.R. (1996), "Interdependency, contracting, and relational behavior in marketing channels", Fournal of Marketing, Vol. 60 No. 4, pp. 19-38.

McDonald, G.W. (1981), "Structural exchange and marital interaction", fournal of Marriage and the Family, Vol. 43 No. 4, pp. 825-39.
McEvily, B., Perrone, V. and Zaheer, A. (2003), "Trust as an organizing principle”, Organization Science, Vol. 14 No. 1, pp. 91-103.

Marsh, H. and Hocevar, D. (1985), "Application of confirmatory factor analysis to the study of self-concept: first- and higher order factor models and their invariance across groups", Psychological Bulletin, Vol. 97 No. 3, pp. 562-82.

Mayer, R.C., Davis, J.H. and Schoorman, F.D. (1995), "An integrative model of organizational trust", Academy of Management Review, Vol. 20 No. 3, pp. 709-34.

Merritt, A. (2000), "Culture in the cockpit: do Hofstede's dimensions replicate?", fournal of Cross-cultural Psychology, Vol. 31 No. 3, pp. 283-301.

Miller, N.J., Besser, T. and Malshe, A. (2007), "Strategic networking among small businesses in small US communities", International Small Business fournal, Vol. 25 No. 6, p. 631.

Mohr, J. and Nevin, J.R. (1990), "Communication strategies in marketing channels: a theoretical perspective", fournal of Marketing, Vol. 54 No. 4, pp. 36-51.

Molla, A. and Sanchez, M. (1997), "Interfirm influence strategies in marketing channels", The International Review of Retail, Distribution and Consumer Research, Vol. 7 No. 3, pp. 249-62.

Moorman, C., Zaltman, G. and Deshpande, R. (1992), "Relationships between providers and users of market research: the dynamics of trust within and between organizations", Fournal of Marketing Research, Vol. 29 No. 3, pp. 314-28.

Morgan, R.M. and Hunt, S.D. (1994), "The commitmenttrust theory of relationship marketing", fournal of Marketing, Vol. 58 No. 3, pp. 20-38.

Nahapiet, J. and Ghoshal, S. (1998), "Social capital, intellectual capital, and the organizational advantage", The Academy of Management Review, Vol. 23 No. 2, pp. 242-66.

Nederhof, A. (1985), "Methods of coping with social desirability bias: a review", European fournal of Social Psychology, Vol. 15 No. 3, pp. 263-80.

Payan, J.M. and McFarland, R.G. (2005), "Decomposing influence strategies: argument structure and dependence as determinants of the effectiveness of influence strategies in gaining channel member compliance", Fournal of Marketing, Vol. 69 No. 3, pp. 66-79.

Pearce, C.L. and Ensley, M.D. (2004), "A reciprocal and longitudinal investigation of the innovation process: the central role of shared vision in product and process innovation teams (PPITs)", fournal of Organizational Behavior, Vol. 25 No. 2, pp. 259-78.

Podsakoff, P.M. and Organ, D.W. (1986), "Self-reports in organizational research: problems and prospects", fournal of Management, Vol. 12 No. 4, pp. 531-44.

Podsakoff, P.M., MacKenzie, S., Lee, J. and Podsakoff, N.P. (2003), "Common method biases in behavioral research: a critical review of the literature and recommended remedies", Fournal of Applied Psychology, Vol. 88 No. 5, pp. 879-903.

Powell, W.W. (1990), "Neither market nor hierarchy: network forms of organization", Research in Organizational Behavior, Vol. 12, pp. 295-336. 
Ravenscraft, D.J. (1983), "Structure-profit relationships at the line of business and industry level", Review of Economics and Statistics, Vol. 65 No. 1, February, pp. 22-31.

Ring, P.S. and Van de Ven, A.H. (1992), "Structuring cooperative relationships between organizations", Strategic Management Fournal, Vol. 13 No. 7, pp. 483-98.

Ruekert, R.W., Walker, O.C. Jr and Roering, K.J. (1985), "The organization of marketing activities: a contingency theory of structure and performance", fournal of Marketing, Vol. 49 No. 1, pp. 13-25.

Rutner, S.M. and Gibson, B.J. (2001), "The effects of survey collection methods on reliability, response rate and costs", Proceedings of the 2001 Council of Logistics Management Educators Conference, Kansas City, MO.

Sakakibara, S., Flynn, B.B., Schroeder, R.G. and Morris, W.T. (1997), "The impact of just-in-time manufacturing and its infrastructure on manufacturing performance", Management Science, Vol. 43 No. 9, pp. 1246-57.

Sanzo, M.J., Santos, M.L., Vazquez, R. and Alvarez, L.I. (2003), "The effect of market orientation on buyer-seller relationship satisfaction", Industrial Marketing Management, Vol. 32 No. 4, pp. 327-45.

Sawhney, R. (2006), "Interplay between uncertainty and flexibility across the value-chain: towards a transformation model of manufacturing flexibility", fournal of Operations Management, Vol. 24 No. 5, pp. 476-93.

Schmalensee, R. (1985), "Do markets differ much?", The American Economic Review, Vol. 75 No. 3, pp. 341-51.

Schurr, P.H. and Ozanne, J.L. (1985), "Influences on exchange processes: buyers' preconceptions of a seller's trustworthiness and bargaining toughness", fournal of Consumer Research, Vol. 11 No. 4, pp. 939-53.

Skrondal, A. and Rabe-Hesketh, S. (2005), "Structural equation modeling: categorical variables", in Everitt, B. and Howell, D. (Eds), Encyclopedia of Statistics in Behavioral Science, Wiley, London, pp. 1-8.

Slack, N. (2005), "The flexibility of manufacturing systems", International Fournal of Operations \& Production Management, Vol. 25 No. 12, pp. 1190-200.

Smith, J.B. and Barclay, D.W. (1997), "The effects of organizational differences and trust on the effectiveness of selling partner relationships", fournal of Marketing, Vol. 61 No. 1, pp. 3-21.

Spekman, R.E., Kamauff, J. and Spear, J. (1999), "Towards more effective sourcing and supplier management", European fournal of Purchasing and Supply Management, Vol. 5 No. 2, pp. 103-16.

Stinchcombe, A.L. (1986), "Norms of exchange", Stratification and Organization: Selected Papers, Cambridge University Press, Cambridge, pp. 231-67.

Stuart, T.E. (2000), "Interorganizational alliances and the performance of firms: a study of growth and innovation rates in a high-technology industry", Strategic Management fournal, Vol. 21 No. 8, pp. 791-811.
Thibaut, J. (1968), “The development of contractual norms in bargaining: replication and variation", fournal of Conflict Resolution, Vol. 12 No. 1, pp. 102-12.

Tsai, W. and Ghoshal, S. (1998), "Social capital and value creation: the role of intrafirm networks", The Academy of Management fournal, Vol. 41 No. 4, pp. 464-76.

Upton, D.M. (1995), "What really makes factories flexible?", Harvard Business Review, Vol. 73 No. 4, pp. 74-84.

Venkatraman, N. (1989), "The concept of fit in strategy research: toward verbal and statistical correspondence", Academy of Management Review, Vol. 14 No. 3, pp. 423-44.

Venkatraman, N. and Ramanujam, V. (1986), "Measurement of business performance in strategy research: a comparison of approaches", Academy of Management Review, Vol. 11 No. 4, pp. 801-14.

Vickery, S., Calantone, R. and Droge, C. (1999), "Supply chain flexibility: an empirical study", The fournal of Supply Chain Management, Vol. 35 No. 3, pp. 16-24.

Vorhies, D.W., Harker, M. and Rao, C.P. (1999), "The capabilities and performance advantages of market-driven firms", European fournal of Marketing, Vol. 33 Nos 11/12, pp. 1171-202.

Voss, C.A. (2005), "Alternative paradigms for manufacturing strategy", International fournal of Operations \& Production Management, Vol. 25 No. 12, pp. 1211-22.

Wathne, K.H. and Heide, J.B. (2004), "Relationship governance in a supply chain network", Fournal of Marketing, Vol. 68 No. 1, pp. 73-89.

White, G.P. (1996), "A meta-analysis model of manufacturing capabilities", Fournal of Operations Management, Vol. 14 No. 4, pp. 315-31.

Wong, A., Tjosvold, D. and Yu, Z. (2005), “Organizational partnerships in China: self-interest, goal interdependence, and opportunism", fournal of Applied Psychology, Vol. 90 No. 4, pp. 782-91.

Wu, F., Yeniyurt, S., Kim, D. and Cavusgil, S.T. (2006), "The impact of information technology on supply chain capabilities and firm performance: a resource-based view", Industrial Marketing Management, Vol. 35 No. 4, pp. 493-504.

Zaheer, A., McEvily, B. and Perrone, V. (1998), "Does trust matter? Exploring the effects of interorganizational and interpersonal trust on performance", Organization Science, Vol. 9 No. 2, pp. 141-59.

Zhang, Q., Vonderembse, M.A. and Lim, J.S. (2002), "Value chain flexibility: a dichotomy of competence and capability", International fournal of Production Research, Vol. 40 No. 3, pp. 561-83.

Zhang, Q., Vonderembse, M.A. and Lim, J.S. (2003), "Manufacturing flexibility: defining and analyzing relationships among competence, capability, and customer satisfaction", Fournal of Operations Management, Vol. 21 No. 2, pp. 173-91. 


\section{Appendix}

Table Al Variables, definitions, and illustrative measures

\begin{tabular}{|c|c|c|c|c|}
\hline Hypothesis & Variables & Conceptual definition & Operation measure items & $\begin{array}{l}\text { Relevant } \\
\text { references }\end{array}$ \\
\hline $\begin{array}{l}H 1, H 2, H 4, \\
H 6\end{array}$ & Volume flexibility & $\begin{array}{l}\text { The ability to change the level } \\
\text { of aggregated output }\end{array}$ & $\begin{array}{l}\text { Suppliers can operate efficiently at different levels of output } \\
\text { Suppliers can operate profitably at different production volumes } \\
\text { Suppliers can economically run various batch sizes } \\
\text { Suppliers can quickly change the quantities for our products } \\
\text { produced } \\
\text { Suppliers can vary aggregate output from one period to the next } \\
\text { Suppliers can easily change the production volume of a } \\
\text { manufacturing process }\end{array}$ & Zhang et al. (2003) \\
\hline
\end{tabular}

$H 1, H 2, H 4, \quad$ Mix flexibility H6

$\boldsymbol{H} \mathbf{1}, \boldsymbol{H} \mathbf{2}, \boldsymbol{H 4}$, New product H6 flexibility

$H 1, H 2, H 4$, Delivery flexibility H6

H1 Promises

H1 Threats
The ability to change the range Suppliers can produce a wide variety of products in their plants of products made within a given time period

The ability to introduce novel products, or to modify existing ones

The ability to change planned or Suppliers are able to make dependable delivery promises assumed delivery dates

The source provides specific rewards if the target conforms to the source's stated desires

The source threatens the target We make it clear that failing to comply with our requests will result Boyle et al. (1992) with future negative sanctions in penalties against suppliers' business

if the target does not comply We threaten lesser purchase to suppliers' business should they fail to with a request
Suppliers can produce different product types without major changeover

Suppliers can build different products in the same plants at the same time

Suppliers can produce, simultaneously or periodically, multiple products in a steady-state operating mode

Suppliers can vary product combinations from one period to the next Suppliers can changeover quickly from one product to another

Suppliers can reduce the time to modify existing products

Chan (2003);

D'Souza and order

Suppliers are able to minimize the time or cost of new products introduced into production

Suppliers can provide the design support in new products pre-launch

Suppliers can deliver its products on promised due dates Suppliers can deliver in smaller lots and ship more frequently to replenish our stock levels

Supplier can to move planned delivery dates forward to accommodate rush orders or special orders

Suppliers can meet the accuracy of delivery quantities

actions of suppliers

We provide price premiums or other incentives for suppliers' participation or cooperation in product quality improvement, new product design, and other manufacturing actives

We offer specific incentives for suppliers to make changes in manufacturing and/or operating procedures

We offer more orders for suppliers' meeting cost-down margin or delivery quantities

We offer incentives to suppliers when they initially had been reluctant to cooperate with a new program or policy

Zhang et al. (2003)

Williams (2000); Koste and Malhotra (1999)

Chan (2003); Duclos et al. (2003); Krause et al. (2001); Sawhney (2006)

Boyle et al. (1992) agree to our requests

We use threats of disturbing suppliers' business, such as slow payment time for supplies, holding payment, and lower pull-in rates We communicate our ability to make "things difficult" for suppliers' business if specific demands are not met

We state that specific orders will be discontinued for not complying with requests

We threaten to reduce the amount of business suppliers will do with our firm, should our demands not be met 
Table Al

\begin{tabular}{|c|c|c|c|c|}
\hline Hypothesis & Variables & Conceptual definition & Operation measure items & $\begin{array}{l}\text { Relevant } \\
\text { references }\end{array}$ \\
\hline$H 1$ & Legalistic pleas & $\begin{array}{l}\text { The source contends that the } \\
\text { target's compliance is required } \\
\text { by legal contract or agreement }\end{array}$ & $\begin{array}{l}\text { We refer to portions of purchasing agreement which favor our } \\
\text { position to gain suppliers' compliance on a particular demand } \\
\text { We make a point to refer to any legal agreements we have when } \\
\text { attempting to influence suppliers' actions } \\
\text { We remind suppliers that any of their obligations stipulated in } \\
\text { purchasing agreement } \\
\text { We use sections of our purchasing agreement as a "tool" to get } \\
\text { suppliers to agree to our demands }\end{array}$ & Boyle et al. (1992) \\
\hline$H 2$ & Requests & $\begin{array}{l}\text { The source simply asks the } \\
\text { target to act without } \\
\text { mentioning or directly implying } \\
\text { subsequent sanctions } \\
\text { requested or rewards }\end{array}$ & $\begin{array}{l}\text { We ask for supplies' compliance to our requests, not indicating any } \\
\text { positive or negative outcome for their business contingent on their } \\
\text { compliance } \\
\text { We ask suppliers to accept new ideas without an explanation of } \\
\text { what effect it will have on their business } \\
\text { We ask suppliers' cooperation in implementing new programs } \\
\text { without mentioning rewards for complying, or punishments for } \\
\text { refusing We expect that our requests do not require an incentive for } \\
\text { suppliers to comply }\end{array}$ & Boyle et al. (1992) \\
\hline$H 2$ & $\begin{array}{l}\text { Information } \\
\text { exchange }\end{array}$ & $\begin{array}{l}\text { The source supplies general } \\
\text { issues to alter the target's } \\
\text { perspectives without stating a } \\
\text { request }\end{array}$ & $\begin{array}{l}\text { We focus on general strategies (as opposed to specific tactics) as to } \\
\text { how to make suppliers' business more profitable } \\
\text { We concentrate more on strategic, long-term issues, rather than } \\
\text { specific courses of action suppliers' business should take } \\
\text { We discuss the orientation our management personnel should take } \\
\text { with regard to long-term planning, rather than daily activities } \\
\text { We attempt to change suppliers' perspective by looking at how } \\
\text { suppliers' business decisions affect the "big picture" }\end{array}$ & Boyle et al. (1992) \\
\hline$H 2$ & Recommendations & $\begin{array}{l}\text { The source stresses that the } \\
\text { target will be more profitable if } \\
\text { the target achieves specific } \\
\text { desired outcomes }\end{array}$ & $\begin{array}{l}\text { We make it clear that by following our recommendations, suppliers' } \\
\text { business would benefit } \\
\text { We make it explicit, when making a suggestion, that it is intended } \\
\text { for the good of suppliers' operation } \\
\text { We provide a clear picture of the anticipated positive impact on } \\
\text { suppliers' business a recommended course of action will have } \\
\text { We outline the logic and/or evidence for expecting success from the } \\
\text { specific programs and actions suggested }\end{array}$ & Boyle et al. (1992) \\
\hline$H 3, H 5$ & Trust & $\begin{array}{l}\text { A party has confidence in the } \\
\text { exchange partners' reliability } \\
\text { and integrity }\end{array}$ & $\begin{array}{l}\text { Our suppliers have been open and honest in dealing with us } \\
\text { Our suppliers respect the confidentiality of the information they } \\
\text { receive from us } \\
\text { Our transactions with suppliers do not have to be closely supervised } \\
\text { We believe that suppliers are trustworthy. We believe suppliers are } \\
\text { committed to us } \\
\text { We have complete confidence in suppliers' motives } \\
\text { Maintaining this relationship is vital } \\
\text { We share with suppliers a similar sense of fair play } \\
\text { Rewards are shared equitably between us and suppliers }\end{array}$ & $\begin{array}{l}\text { Kozak and Cohen } \\
\text { (1997); Kumar et al. } \\
\text { (1995); Spekman } \\
\text { et al. (1999) }\end{array}$ \\
\hline$H 4, H 5$ & Shared vision & $\begin{array}{l}\text { A shared vision is a clear, } \\
\text { common, specific picture of a } \\
\text { truly desired future state }\end{array}$ & $\begin{array}{l}\text { We and our suppliers have a similar understanding about the aims } \\
\text { and objectives of the supply chain } \\
\text { We and our suppliers have a similar understanding about the } \\
\text { importance of collaboration across the supply chain } \\
\text { We and our suppliers have a similar understanding about the } \\
\text { importance of improvements that benefit the supply chain as a } \\
\text { whole }\end{array}$ & Li and Lin (2006) \\
\hline H5 & Performance & $\begin{array}{l}\text { Customers' response in term of } \\
\text { satisfaction and new projects } \\
\text { Market share and revenue } \\
\text { reflect the growth domains of } \\
\text { performance }\end{array}$ & $\begin{array}{l}\text { Market share growth relative to our competition } \\
\text { Growth in sales of our product } \\
\text { Customer satisfaction } \\
\text { Customer new project }\end{array}$ & Vorhies et al. (1999) \\
\hline
\end{tabular}




\section{About the authors}

Po-Young Chu is Professor of the Department of Management Science and a former director of EMBA programs at National Chiao Tung University in Taiwan. He is also a Fellow of the Chinese Society for Management of Technology. His research interests include innovation, entrepreneurship, and strategy management. His publications have appeared in Fournal of Behavioral Decision Making, Technological Forecasting E Social Change, European Fournal of Marketing, International fournal of Production Economics and Fournal of Business-to-Business Marketing.

Kuo-Hsiung Chang, $\mathrm{PhD}$, is a Professor of International Business and Marketing at Tunghai University, Taiwan. His research interests include relationship learning, international strategic alliances, interorganizational conflict management, marketing channel management, and supply chain management. His publications have appeared in fournal of World Business, Industrial Marketing Management, Health Care Management Review, Fournal of Business-to-Business Marketing, and International Fournal of Technology Management.

Hsu-Feng Huang received his $\mathrm{PhD}$ from the Department of Management Science of National Chiao Tung University, Taiwan. His research interests include supply chain management and industrial marketing, innovation, and strategy management. His research has appeared in fournal of Business-to-Business Marketing and Industrial Marketing Management. Hsu-Feng Huang is the corresponding author and can be contacted at: frank.ms94g@nctu.edu.tw

\section{Executive summary and implications for managers and executive readers}

This summary has been provided to allow managers and executives a rapid appreciation of the content of the article. Those with a particular interest in the topic covered may then read the article in toto to take advantage of the more comprehensive description of the research undertaken and its results to get the full benefit of the material present.

Anyone who is or has been a teacher or a parent - or indeed an employer - knows that it is good to be reasonable and persuasive when wanting people to do your bidding, maybe to change their behavior and to act in a more appropriate way. No pressure - just requests, recommendations and certainly no hint of any "or else!" threat.

Sometimes, however, such attempts at influencing someone else's behavior are not guaranteed to result in compliance. It is the same with business where companies can find themselves with a "stick or carrot" dilemma in choosing the most appropriate and effective "influence strategy" to encourage a supplier to increase its flexibility.

Supplier flexibility has become an extremely important issue in today's rapidly changing markets due to the growing importance of purchasing as a means to improve the supply chain. Environmental turbulence is the primary reason for seeking a partner who can be flexible enough to work with the uncertainty of various customer requests. Accommodating customer demand is a necessary condition for a manufacturer's survival. A flexible supplier can increase a manufacturer's competitive advantage by improving response time to customers' ever-changing demands. Unfortunately, although responding to manufacturers' requirements creates values for the manufacturer, it may also lead to a decrease in value for the supplier. Such flexibility implies that suppliers are able to provide additional service in response to changes in market demand, and although this flexibility benefits the manufacturer, it may come at a cost to the supplier.

Suppliers generally provide either limited flexibility, or offer prices based on the level of flexibility desired by the manufacturer. Understanding the means by which manufacturers manage supply flexibility is a crucial issue for management and practice. Volume flexibility is the ability to change the level of aggregate output; mix flexibility the ability to change the range of products produced within a given time period; product flexibility the ability to introduce novel products, or to modify existing ones; and delivery flexibility the ability to alter planned or assumed delivery dates.

In the context of the supply chain, influence strategies refer to the content and structure of communications employed by a manufacturer to influence the attitudes and behavior of suppliers. They include:

- Promises. The source offers specific rewards if the target conforms to the stated desires of the source.

- Threats. The source threatens the target with future negative sanctions if the target fails to comply with a request.

- Legalistic pleas. The source contends that legal contracts or agreements require the compliance of the target.

- Requests. The source simply asks the target to act without mentioning or directly implying subsequent sanctions, requests, or rewards.

- Information exchange. The source provides general information related to issues, to alter the target's perspectives without stating a request.

- Recommendations. The source describes how the target could benefit if it achieves the specific desired outcomes.

Threats, legalistic pleas, and promises are coercive influence strategies; and classified requests, information exchange, and recommendations non-coercive influence strategies. Within the context of the supply chain, coercive influence strategies refer to the direct pressure (e.g., rewards and punishments) a manufacturer puts on a supplier to perform a specific behavior by stressing the negative implications of noncompliance. A threat is a tactic wherein a manufacturer states that failure to deliver a desired action will cause the supplier to lose future business opportunities. The legalistic pleas strategy involves a manufacturer citing obligations within the purchasing agreement to coerce suppliers to perform particular actions. A promise yields rewards (i.e. by price premiums, more orders) if the supplier complies with the manufacturer's requirements. If the supplier does not comply with the manufacturer's requirement, a depreciation of the reward could imply an imposition of sanctions.

While non-coercive strategies may be the preferred option, coercive strategies have clearer intentions. In "How to increase supplier flexibility through social mechanisms and influence strategies?" Po-Young Chu et al. conclude that noncoercive strategies are ineffective in improving supplier flexibility. Non-coercive strategies are not compulsory and therefore suppliers may choose not to comply. They also require considerable time to be realized. The study also 
demonstrates that shared vision positively influences supplier flexibility, but trust does not.

Shared vision implies a stronger inter-organizational cohesiveness, increasing communication between the manufacturer and suppliers. Frequent communication and interaction can help develop common goals and mutual understanding. To achieve the flexibility required in an unpredictable supply chain, manufacturers and suppliers need to incorporate high levels of cooperation and joint planning. In addition, the promotion of supplier flexibility may require an increase in investment or involvement (e.g. training workers, R\&D expenditures, capacity expansion). Therefore, suppliers with a shared vision consider the benefits of the entire supply chain and make more of an effort to comply with the manufacturer's demand for increased flexibility.

(A précis of the article "How to increase supplier flexibility through social mechanisms and influence strategies?". Supplied by Marketing Consultants for Emerald.)

To purchase reprints of this article please e-mail: reprints@emeraldinsight.com Or visit our web site for further details: www.emeraldinsight.com/reprints 